International Journal of Engineering \& Technology, $7(4.38)(2018) 1200-1204$
International Journal of Engineering \& Technology
SPC
Website: www.sciencepubco.com/index.php/IJET
Research paper

\title{
Perspective Lines System in A.S. Makarenko's Pedagogical Experience
}

\author{
S.S. Nevskaja ${ }^{1 *}$, E. Mettini ${ }^{2}$ \\ ${ }^{1}$ Center of history of pedagogy and education, FSBSI "Institute for Strategy of Education Development of Russian Academy of \\ Education", ul Makarenko, 5/16, Moscow, Russia, 105062 \\ ${ }^{2}$ FSBEI of Higher Education RSMRU "Pirogov", Mettini Emiliano, ul. Ostrovityanova 1, Moscow, Russia, 117997 \\ *Corresponding author E-mail: s.s.nevskaja@mail.ru
}

\begin{abstract}
In the paper is investigated perspective lines system created by A.S. Makarenko, are covered problems concerning psychological time and space, meaning of life, self-actualization, consciousness and self-awareness of individual. The individual perspective is regarded as an element of evolving self-awareness of former young offenders and homeless children. In human self-awareness, structure start evolving when there are representations of in the past, present and future. In the paper are provided insights into the connection of individual time perspective and individual morality, is proved that perspective lines system fulfills a very important function in defining moral value of man and that inside Makarenko's collective individual developed in himself those qualities that helped to enter adult life worthy and find his place in community (society).
\end{abstract}

Keywords: perspective lines system, near-term perspective, middle-term perspective, long-term perspective, psychological individual time, meaning of life, self-actualization, consciousness and individual self-awareness, collective and individual, morality, ethics and integrity.

\section{Introduction}

A.S. Makarenko created an ingenious perspective lines system, whose spatial-temporal background organized a pedagogicalexistential continuum in which collective of Colony named after M. Gorky and Commune named after. F.E. Dzerzhinsky developed.

In A.S. Makarenko's opinion, individual perspective is preeminently an element of evolving self-awareness of his pupils, former young offenders, homeless children and teenagers of both genders. For the first time, pedagogue shown that there is a tight connection between individual time perspective and individual morality, and that perspective lines system fulfills a very important function in defining individual moral value. In Makarenko's collective individual developed in himself those qualities that helped to enter adult life worthy and find his place in community (society). In colony, (commune) special conditions and situations were created for improving self-organization of individual and of "his autonomy as citizen", capable of making his own decisions. Were created conditions in which individuality of each colonist (communard) might develop his individual dispositions and abilities and make his own way to life.

\section{Discussion}

In opinion of American scholar H. Murray, the human desire of autonomy and searching the ways to fulfill the meaning of life is a natural need promoting development of a healthy individual. Above quoted scholar by autonomy meant liberation from restraining bonds, resistance to coercion, aspiration to be independent, to act in compliance with personal convictions, to not be bound by anything, to disregard conventions. By A.S. Makarenko, namely the "perspective lines system" promoted the process of self-actualization and self-implementation of such individual. In his educational experience, the perspective line system is nothing but implementation of theory of future joy in collective children life, on whose basis laid the theory of individual psychological time. The pedagogue reckoned that "in the first instance is needed to organize joy as such, to call her into existence, and consider her as real. Secondarily, it is needed to transform same simple kinds of joy into more complicated and significant for people" [1, v.1, p. 311]. In this theory he had developed Anton Semenovitch exposed himself as individual, whose meaning of live was "to be source of warm light for other people. To be the consciousness of the Universe and the conscience of human kind. To be the reformer of life, eradicating all vice from it and incessantly culturing life" in the words of psychologist S.L. Rubinstein [2, p. 381].

Scholars studying A.S. Makarenko's works, look at pedagogue like a man who was a great humanist in our troubled century. When Anton Semenovitch suggested to his pupils to write their life histories and send them to their patron and friend of Colony Maxim Gorky as gift (supposing that these life histories might serve as material for creative plots) something unexpected happened. After he had read and typewrote hundredth life history, pedagogue understood that he was reading a really shocking book, inside which gathered children's misfortune. Anton Semenovitch used these words to express his impressions of what he had read: "In those simple lines I found the expression of their views about life, a part of a philosophy, of such philosophy that can and must appear among such well-defined group like "homeless 
children"...In each line I feel that those stories don't claim to excite no one's pity, to make impression, there were only a simple, sincere story of a little, abandoned and lonely man, who is already used to rely upon any pity, used to hostile environments, who is used to not be uneasy in such status". For me, in this tragedy, perhaps, there is more substance than for somebody else. During eight years not only I had to look at dreadful misfortune of left in the lurch children, but and terrible moral deviations of such children. I had no right to limit myself to commiseration and compassion toward them. It was clear to me that for their salvation I must be inflexibly exigent, severe and steady. Toward their misfortune, I must be such a philosopher as they are toward themselves. Herein my tragedy, that I felt especially when I read those reports. And it must our common tragedy, that we have no right to avoid" [1, v.1, p. 91].

The great importance of A.S. Makarenko's works is that he set himself a really important and vital goal (and achieved it). $\mathrm{He}$ gave his pupils quotidian and continuous feeling of joy in living, feeling of a pleasant perspective in the day to come, feeling of their importance and security in infantile and adult working collective, inside which worked a well-organized self-government. At these goals, he originated a particular moral, emotional style for children life (ethos of life). Totally rejecting provoking, arrogant, shameless and depressed style of children's collective, pedagogue greeted major lifestyle, the mix of respect and exactingness toward children, the comradely unity of members of collective, the sensation of personal dignity, the feeling of security, activity and skill to control behavior. Makarenko connected such idea as "educational style" with holistic features of lifestyle in colony and of style of life among colonists and relations inside collective.

A.S. Makarenko wrote that "major lifestyle" in collective must be really calm and firm. It is not so difficult to imagine that, creating a style of children's life, Anton Semenovitch from psychological standpoint, sagaciously set former homeless children's and young offenders' consciousness on an inner positive tranquility, confidence in their own strength, in the strength of collective and in their future. Pedagogue created a living space for children and adults, where everything was all right and everyone was protected. It is necessary take into account another fact, while analyzing Makarenko's educational experience from the standpoint of perspective lines system. The major lifestyle must look like a continuous vivacity, readiness to a vigorous, calm and efficient action without tumultuousness and planeless. "Such vivacity, in pedagogue's opinion, is attained only in collective that often does practice in executing different tasks. Tasks are fulfilled not by all in one, but orderly with a precise designation of functions of singular organs and people, with a sharply defined and direct responsibility of singular people and all collective" $[1, \mathrm{v} .1, \mathrm{pp}$. 316-317].

Outstanding psychologist S.L. Rubinstein firstly made emphasis upon that Makarenko set as his goal development of children's consciousness nourishing in them defined important relations that evolved in their real behavior, in acts and conduct of children's collective members. He created a spatial-temporal model in which consciousness and behavior of pupils are discussed in term of near-term perspective, middle-term perspective, and long-term perspective. A.S. Makarenko thought that to educate man means to educate in him perspective lines. Principles of such work are the organization of new perspectives, using those already in place, and continually replacing them with more valuable. It is possible start with a good meal and a visit to circus, but it is needed every time call into existence and continually broad perspective of collective, bring them up to perspective of all Soviet Union" [1, v.1, p. 311]. In man it is needed to appreciate not only strength and beauty (we are used to do it, appreciating them in individual), Makarenko asserted, but the way man thinks about perspective. If man acts only using a short-term perspective, he is a wake man. If him satisfies only his own perspective, that man may be strong, but he does not evoke "sensation of beauty and her real value. (...) The broader the collective is, whose perspectives are for man his own personal, the most beautiful and highest the man is" $[1, \mathrm{v} .1, \mathrm{p}$. 311]

In draft manuscript of "Pedagogical Poem" are kept the following utterance of Anton Semenovitch about this topic:

"Organization of perspective and its transformation into a social element from a personal one is my main task. Each pleasant perspective, if it is already organized, inevitably improves lifestyle at all and, preeminently, the human ability to work" $[1, \mathrm{v} .3, \mathrm{p}$. 471]

Further A.S. Makarenko reasoned about that the increment of productive of work is not due only to salary, and that the reason why people try to earn as much as possible but is the representation about the future earning and connected to it perspectives that improves general identity of individual, his energy and cultivates his attitude toward the world.

In collective perspective this fact is more evident. On the basis of such reasoning, Anton Semenovitch summed up the following conceptual view: "To give collective a proper education means surrounding it with a really complex system of representations concerning perspective, everyday promoting pleasant representations about future, cheering people and filling with joy their today [1, v.3, p. 472].

Knowing the traumatic past of his pupils, pedagogue made every effort to "block" such past. For instance, was created such ritual like burning clothes of homeless children (farewell with the past), was strictly forbidden to remember such past (adults have never thrown the past in their face) and so on. Such methodological approach by which the "traumatic past was ignored" in a certain way "stopped" psychological time of pupil at the moment before he entered colony, forced him to remove it, to forget about hard past life, to live in present, live for happy and pleasant forwardlooking optimism along with his comrades having had the same destiny in the past [3].

Tomorrow must look "better than today in children's collective in which are people not capable of displaying very far in advance their strivings and interests. The older you are the furthest shift the natural borderline of optimistic perspective. For a boy aged 15 or 16 the short-term perspective has not the same great value than for a teenager aged 12 or 13 . For adult it is more than enough only far-term perspective, in dependence of his consciousness and political development of such individual" [1, v.1, p. 312], A.S. Makarenko wrote. Pedagogue reckoned that it is necessary to educate collective, social relevant motivational lines, and not only individual. Moreover, in harmonizing individual and collective perspective lines, no contradictions between them must be noticed. It is necessary to organize short-term perspective and this latter must start from personal perspective lines. A.S. Makarenko thought that first stage of such organizational work must be mandatory for every educational institution. Under such work he classified this necessary minimum of perspective, without which it is impossible to start a right educational work. To such minimum refer "equipped accommodations and classes, warm rooms, satisfactory food, clean bed, full feeling of protection from tyranny and despotism of older boys, cordial, simple style of relations" [1, v.1, p. 312].

But how to deal with them, for whom the ordered life of children's institutions is not so attractive as to force to forget usual tendencies? A.C. Makarenko devoted all his life to solution of this question. He understood that to him had come teenagers whose short-term perspectives had a negative character. They did their best to "show their strength over fakest comrades, to defiantly rude behave to girls, to tell nasty jokes". They took possession of something material stealing it, they have propensity to wine, that were "also needs placed on short-term perspective". Moreover "playing at cards, out drinking, mocking over others is possible even in the same comfortable living conditions". Consequently, in young collective at any moment might take place fight against old and new perspective lines. Especially during this time the highest priority must be given to organization of short-term perspective. 
Cinema, recitals, parties, work of club circles, readings, amateur talent activities, promenades and tours must push aside primitive kinds of "pleasant" amusements" [1, v.1, p. 312].

In addition, it is not necessary to base the short-time perspective on principle of pleasure. It is needed to build it up according to a collective plane. Then it is necessary rely on these guys notable for dynamic aspects of character (active, with ambition, needing to stand out of the crow and to prevail, and convert their interest into more valuable kinds of satisfaction. Further, A.S. Makarenko suggests giving pupils the chance of straining after such kind of satisfaction needing some job. It is necessary to ensure that original simple perspective (for instance making a comfortable alley, cleaning pound, building an ice rink and so on) was replaced by a more relevant perspective concerning the fulfillment of a task as best as possible. So, cleaning alley, guys proposed to make it bigger, and such work needed great efforts, more guys and they were involved in work for a longer period. Making room for ice rink, captured by simple and not relevant perspective of amusement, guys were catch by the perspective of installing lights, benches, warmers and so on. Such pleasant perspective, Makarenko remarked, gradually was replaced by a more valuable kind of interest and advancement in their works. He noticed that such interest arose in everyone, and he saw that during this process in someone made appearance other lines of short-term perspective: organizational and managerial solutions.

Collective developed, turning into a friendly family, and it takes only representation of collective work to enrapture all by a pleasant short-term perspective. Reflection had taken place, a critical revaluation of past, present and future values. All this is connected with individual and collective temporal perspective, with concretization and differentiation of goals and motivations Integration and hierarchy of individual motivations, inside a stable core of system of value pay a huge role (I.S. Kon). Managers of children's institutions must learn how to organize short-term perspective, "a common action aimed at tomorrow, that is full of collective success" (A.S. Makarenko). Here it is important to set the mood so that pupils, waking up, were already captured by today pleasant perspective. The passage from present to near future must be certainly pleasant. Such expectation ought not to be only expectation of simple amusement and immediate satisfaction. It must be joy for a successfully achieved work, for future success. For instance, it is important to help student to learn a lesson, so that he could wake up in the morning with a good perspective and so on. The optimism of perspective arises even when at school is announced a competition of smartness, or a football match is about to take place and so on.

Through his own experience, A.S. Makarenko became certain that "every joy, even a little one staying in front of collective makes it stronger, more friendly and active. Sometimes, must be set a difficult and worthy of not task, other times it is necessary only to give collective the simplest satisfaction for children: in one week you have ice cream" [1, v.1, p. 314].

Mid-term perspective, Makarenko reckoned, was a "project of a collective event, a little postponed in time. Such event must not to be frequent. Among them: participation in celebratory demonstrations, festival, anniversary of children's institution, round dates of honorable patrons after whom institutions are named, graduation, beginning and end of school year, summer vacation and so on. Preparations for mid-term perspective must be made in advance: in it there is their relevance. In A.S Makarenko's practice such holidays (mid-term perspective) were no more than two or three times a year. Firstly, sprung up a common idea about holiday, then were elected committees involving as more pupils as possible, was prepared a plan to celebrate holiday and so on.

Pupils of Commune visited Crimea, Moscow, and Caucasus, travelled down the Volga. They made preparations to such midterm perspective of holiday vacation all year long. Kind and best arrangements for summer holiday depended on merits of collective, on development of production, self-organization and cultural work.

In A.S. Makarenko's institutions preparation to implementation of mid-term perspective had the features of a competition, was a creative process and expectation of pleasant holiday. Often pupils remembered those remarkable tours. In his book "Makarenko brought us up", L.V. Konisevitch described Caucasian tour. In the seventh chapter (Stages of tour) we can read: "Caucasian tour! All year long we have been dreaming of it and preparing for it. All shops fulfilled industrial and financial plan. A rest was really needed. After intensive production work, school and other kinds of stress relaxation was required [4, p.203].

What kind of life was, if relaxation is required? L.V. Konisevitch wrote about this: "Nothing but common life in collective with its happiness and sorrows, successes and fails, in emotional experience of life troubles and their surmounting brought people together. In wonderful accommodations one hundred fifty communards lived, studied at school, worked, competed with each other, met guests, played in the band, railed at Solomon Borisovitch, dreamt about future. Life was led by an expert hand, subordinate to a steady system, that we supported, fought for it and tried not to let failures happen. That's why life was easy and free. We were all different what concerns age, aspect, habits, character, inclinations, tastes, personal abilities but, at the same time we had something common: the desire to become people who can be good for others, for society. Such perspective seemed so far away in the future, we prepared for it, but at that time we lived all tighter and we thought that it would last for a very very long time".

We permit ourselves to quote one more piece from L.V. Konisevitch's book. "In commune we loved dreaming. Dreams were different: about tours, about new fabric, workers' school, about the future after commune. Dreams anticipate life and life dictates us its laws. Life forces you to make experience with unexpected situations, and sometimes with regrettable fails. Our dreams arose on a real basis and come true thanks to great desire and work of whole collective. Dreams turned into a concrete task and submitted to themselves all our human and material resources. All pupils who go out from talented Makarenko's hands shared those thoughts. Makarenko understood that sooner or later his pupils would enter real life and stay in commune is just a temporary status. Nevertheless, he did his best to make so that the main long-term perspective didn't become apathy toward to further future of his own institution where they felt so good and joyously. He set for collective the goal to make the life of commune richer and more cultured. Such high goal, pedagogue reckoned, has to throw light on "many details of today life". "Such remote perspective may lead guys to extensive works and stress, really may be for them a pleasant perspective, indeed". Such fact is based on natural instinct of each pupil as part of the family.

Here it must be understood that in A.S. Makarenko's opinion the educational collective was a big family, an extended family, as he called it. It means that no one was indifferent to destiny of his institution, his home. This perspective of taking care of the future of his home firmly tied alumni. They had material support, the room of their combined brigade was kept free when they came for recreation during holidays, with them was conducted a regular correspondence. Such perspective is linked to great national perspectives. No less important is the future perspective of each pupil. On the background of enormous future development in still young Soviet Union, the pedagogue tried to draw up long-term perspective for some pupils. "As pupil of children's institution start learning at school and at manufacturing site - Makarenko wrote - only is future was of interest for him".

About farewell with commune, his feelings concerning life spent there, L.V. Konisevitch wrote following:

"And the day when I would leave commune has come. I didn't sleep well last night. Memories flown as a restless river, endless thoughts washed over me. As the sun had come up, I woke up and went to the courtyard. I wanted to get out, be alone so that for the 
last time I could go around these cherished places and say them goodbye. The perception of the world had grown in intensity. What I didn't' notice before, became so clear, distinct..." As I had visited shops and had taken leave of craftsmen, workers and comrades - communards, I paid a visit to pedagogues Tatarinov, Tersky, Pushnikov, Magure, Bereznyak, Levshakov, Ruban and others, being fearful of forgetting someone. Delightful and dear people. That's you who brought me up and put me up! That's you who with your affection warmed my soul, taught me to love life. You raised me, you provide an education, gave a profession!

You made all efforts to make me proudly say that I became a man! Deepest gratitude to you, and my everlasting reconnaissance. In confused soul joy and dragging pain. All visible things that I can perceive were dear and close to me, was my home: the blue sky, the garden, the forest, and the fields, and the playgrounds, and the road we got to like, the great buildings and silent sparrows on the cornice...

And how all this will live without me and everything will rest as it is?

Inexorably, these lives slept away from me beyond an invisible line, when there is no more possible enter and never will. That is where left such unique time as childhood.

During those moments when I was thinking, on the edge of present and future, a reflection made appearance: why do we hurry life? For which reason we are in a hurry and strive for future, we do not have time to look over our shoulder to evaluate this splendid present!

These words are the highest grade of A.S. Makarenko and his colleagues' work. L.V. Konisevitch graduated workers' school got letters of reference from pedagogical department and Komsomol committee a certificate of qualification skill of " 5 th level toolmaker", sportive awards, merit certificates and distinctive marks. His dot after graduation were his beloved books and diaries, photos, commemorative gifts, boxing-gloves, cavalry spurs, letters and librettos of spectacles he had attended. "In every item are kept cherished memories!" L.V. Konisevitch and his friend Kolya Gontarenko became students of institute for engineers of water transport named after Gorky.

Time spent in commune seemed to alumni very fast and short, but happy and pleasant despite that all day was very busy scheduled: work, school, clubs and many other important and useful events. Children's life was rich in event, and, indeed, was scheduled by seconds, minutes, days, and weeks and so on. Militarization of life gave a precise rhythm to working day. Dynamism of chronological length of events varied from one minute to one tear. Therefore, for instance, speech at the general assembly has to least no more than one minute. What further occurred to Leonid Vatzlavovitch Konisevitch has its continuation. He left institute and A.S. Makarenko once again accepted him in commune for restoring. Then Konisevitch's dream came true: he became a sailor and so his long-term perspective came to life. In 1938, young Konisevitch was decorated with order of Badge of Honor for having accomplished a feat with a fiery cruise of motor ship "Kursk" saving Spanish children 27 April 1937.

A.S. Makarenko believed that individual long-term perspectives, preeminently, must be connected to prosperity of all society. He admitted that socialism is possible "in the most beautiful forms of human community", but (pedagogue had already written about it in 1922), he believed that "at that moment under sociology does not lay a steady psychological basis, especially what concerned collective psychology, scientific development of socialistic forms is impossible, and without scientific evidence it is impossible a modern socialism" [5, p.444].

\section{Results}

Results of A.S. Makarenko's pedagogical system were his pupils: honest, hard-working, responsible, loving their country and able to defend it, ready to take responsibility for their action people. During Great patriotic war, they displayed heroism, courage and abnegation and in time of peace, they were excellent citizens of their Fatherland.

Actually, perspective lines system and peaceful rhythm of their achievement in A.S. Makarenko's practice normalized the lapse of psychological time, gave it a determinate pace, fashion and major lifestyle of contacts in collective, and gave shape to consciousness and individual self-awareness.

Regulating and saturating with a specific content psychological (subjective) individual time, with a system of methods and approaches (organization of perspective lines, their implementation, rhythm of life, work, rest and amusement) ultimately promoted the development of self-awareness of pupils and its basic structural elements: identification with name (nicknames were forbidden, the reputation of name was restored and defended from offense), gender identification (organization of boys' and girls' life, defense of girls 'honor, cultivation of manhood), claim to recognition (method of responsible subordination, interexchange of leaders, self-government and other way to reach self-actualization and self-esteem), life in psychological time (regularity of life, equality of rights and duties, incentive system) life in social space (organization of collective life, system of collective relationships, contact with patrons, with life of society and country).

It must be said that A.S. Makarenko's psychological time approach reflects theory of determination of human activity. Individual subjective time, given in emotional experience, corresponds to individual time from a psychological standpoint. In human structure of self-awareness psychological time starts forming when there are representations of self in past, present and future. Children and adults have different representations of time. As for children, it is stretched, lapses slowly and fluently. That is why children's representation about live (childhood, youth) looks like an endless and free process. As for adults, psychological time is clenched, concentrate in little slots, live goes fast and fluently. For such reason, there is a link of psychological time with freedom as subjective category. In his practice A.S. Makarenko took into account both these facts. He set for himself the goal of shaping consciousness of children creating for them defined important relations developing in their behavior, acts and actions. Herein, pedagogue reckoned that human actions, reactions and impulses are the result not only of previous and present human development and past experience. Such development is mediated by the future, by that perspective in which is reflected the human representation of live in the future life" [6, pp.62-63].

A.S. Makarenko's practice had shown that efficiency of education and (re)socialization of colonist and communard was granted by perspective lines system. Thus, A.S. Makarenko played an important role in world pedagogy.

\section{Acknowledgements}

This work is carried out in the frameworks of state task by FSBSI Institute for Strategy of Education Development of the Russian Academy of Education for 2017-2019 (No. 27.8089.2017/BC) "Implementation of potential of historical-educational researches in modern pedagogical education".

\section{References}

[1] A.S. Makarenko, Pedagogicheskie socinenja v 8-x tt. [Pedagogical works in 8 volumes], Pedagogika, Moskow, 1983-1986.

[2] S.L. Rubinstein, Problemy obshej psikhologii [Problem of general psychology], Pedagogika, Moscow, 1976.

[3] E. Mettini, Dukhovno-nravstvennye osnovy vospitatelnoj sistemy A.S. Makarenko. K 130-letiju A.S. Makarenko (1888-1939) [Spiritual and ethical basis of A.S. Makarenko's educational system. On the occasion of 130th centenary of the birth of A.S. 
Makarenko], Zhurnal pedagogicheskix issledovanij 2(6) (2017) 60 67.

[4] L.V. Konisevitch, Nas vospityval Makarenko [Makarenko brought us up], Chelyabinsk Regional Institute for Advanced Training and Retraining of Public Education Workers, Chelyabinsk, 1993.

[5] S.S. Nevskaja, Vospitanie grazhdanina $v$ pedagogike A.S Mkarenko v 2 chastyakh. [Education for citizenship in A.S. Makarenko's pedagogy in 2 parts], Akademicheskij proekt, Al'ma Mater, Moskow, 2006.

[6] S.S. Nevskaja, Problema samosoznanija lichnosti in pedagogike A.S. Makarenko (Psikhologicheskoe vremja lichnosti) [Problem of self-awareness in A.S. Makarenko's pedagogy (Individual psychological time)], Pedagogicheskoe obshestvo Rossii, Moskow, 2017. 